\title{
MUHAMMAD IBN ABD AL-RAHMAN \\ (STUDI ATAS PERANANNYA DALAM PENGEMBANGAN FILSAFAT DAN SAINS DI ANDALUSIA)
}

\author{
Anastya Nida Alhana \\ Institut Agama Islam Negeri Purwokerto \\ mishreya_alhana@gmail.com
}

\begin{abstract}
Muhammad Ibn Abd Rahman is known as Muhammad I was the 5th emir during the reign of the Umayyad Dynasty in Spain in 852-886 AD. He was the son of Abdurrahman Bin Hakam a 4th leader of the Umayyad Dynasty in Spain. He died at the age of 65 years coinciding in $886 \mathrm{AD}$ and at the end of his term of office. The beginning of Muhammad I is served as a series of domestic riots. The government shock is began with the Toledo People's rebellion, assisted by the Leon tribal chief to rebel in $854 \mathrm{AD}$, As an emir who was an expert in the administration of his government, he is organized the Andalusian government on a regular basis and created a system of government regulations in the form of legislation. For the management of the State, he also carries out government policies that lead to the welfare of people's lives. Like his father, one of his personalities was to love the art of beauty and science, so that during his reign he built the city by beautifying the capital city with beautiful buildings, large buildings, and monuments, and he was a supporter of the facilities for education, as well as poets and writers also got their attention. His great contribution in advancing Spanish civilization, which is someone who initiated the growth of progress in the field of Islamic Philosophy and Science in Spain, has recorded one sheet of culture in the achievement of Islamic history. The interest in Greek Philosophy and Science began to be developed in the 9th century AD during the reign of the fifth Umayyad, namely Muhammad Ibn Abd al-Rahman (832-886 AD) at the initiative of al-Hakam (961-976 AD), the scientific works, libraries and universities are able to rival Baghdad as the main center of science in the Islamic world.
\end{abstract}

Keywords: Muhammad Ibn Abd Al-Rahman, Philosophy and Science Development in Andalusia

\begin{abstract}
ABSTRAK
Muhammad Ibn Abd Al-Rahman, dikenal dengan Muhammad I merupakan seorang amir ke-5 pada masa pemerinthan Dinasti Ummayah di Spayol pada tahun 852-886 M. Beliau putra dari Abdurrahman Bin Hakam seorang pemimpin ke-4 Dinasti Umayah di Spanyol. Beliau meninggal dunia pada usia 65 tahun bertepatan pada tahun $886 \mathrm{M}$ sekaligus menjadi akhir Masa jabatan pemerinthanya. Awal mula Muhmmad I menjabat
\end{abstract}


terjadi serangkaian kerusuhan dalam negeri. Kegoncangan pemerintahan bemula dari pemberontakan Rakyat Toledo, dibantu kepala suku Leon memberontak pada tahun $854 \mathrm{M}$. Sebagai seorang amir yang ahli dalam ketata pemerintahn beliau mengorganisir pemerintahan Andalusia secara teratur dan membuat sitem peraturan ketata pemerintahan dalam bentuk perundang-undangan bagi pengelolaan Negara, beliau juga melakukan kebijakan-kebijakan pemerinthan yang mengarah pada mensejahterakan kehidupan rakyat. Seperti ayahnya, salah satu kpribadian beliau yang sangat pencinta seni keindahan dan ilmu pengetahuan pada masa pemerinthannya beliau membangun kota dengan memperindah Ibu Kota dengan gedung-gedung indah, bangunan-bangunan besar, serta monumentmonumen. dan beliau penyokong fasilitas bagi pendidikan, serta para penyair dan penulis turut mendapatkan perhatiannya. Kontribusi besar beliau dalam memajukan peradaban Spayol yaitu merupakan seseorang yang meprakarsai tumbuhnya kemajuan dalam bidang Filsafat dan Sains. Kemajuan filsafat dan Sains Islam di Spanyol telah mencatat satu lembaran budaya dalam pencapaian presatsi sejarah Islam. Minat terhadap filsafat dan ilmu pengetahuan Yunani mulai dikembangkan pada abad ke $9 \mathrm{M}$ selama pemerintahan BaniUmayyah ke lima, yaitu Muhammad ibn Abd al-Rahman(832-886 M) atas inisiatif al-Hakam (961-976 M), karya-karya ilmiah dam filosofis diimport dari Timur dalam jumlah besar sehingga Cordova dengan perpustakaan dan Universitasnya mampu menyaingi Baghdad sebagai pusat utama ilmu pengetahuan di dunia Islam.

Keyword: Muhammad Ibn Abd Al-Rahman, Pengembangan Filsafat Dan Sains Di Andalusia

\section{Pendahuluan}

Bangsa Spanyol pada kisaran dua abad sebelum Masehi hingga abad ke-5 merupakan daerah kekuasan imperium Romawi. Islam baru berhasil menaklukan Spanyol pada abad ke-7 dan mulailah istilah Andalusia sebagai nama suatu wilayah diperkenal di Spanyol. Islam menyebut Spanyol sebagai "Andalus" secara etimologi berasal dari kata "Vandal" yaitu nama suatu suku bangsa yang berhasil menaklukkan bangsa Spanyiol sebelum jatuh ditangan bangsa Arab. ${ }^{1}$ Bangsa Arab kemudian menamainya dengan al-Andalusia, yang lebih dikenal dengan nama Andalusia. Sebelum islam datang pada awal abad keenam (507 M) suku-suku Ghathia Barat melakukan ekspasni dan menaklukan Spanyol mereka menyusir bangsa Vandal ke Afrika. Bangsa Ghathia kemudian dapat berhasil mendirikan pemerintahan yang kuat di Andalusia. Penurunan kekuatan dan kekuasaan Bangsa Ghathia terjadi disebabkan merajalelanya perbudakan, kepincangan ekonomi karena petani dan pedagang diharuskan menanggung pajak dan 
pemaksaan agama. ${ }^{2}$ Kondisi penduduk Andalusia yang demikian terjadi sampai Islam datang, sementara kondisi penduduk Afrika Utara hidup dalam keadaan sejahtera di bawah kekuasaan pemerintahan Islam. Maka kedatangan islam di Spanyol sejatinya mendapat dukungan dari warga Spayol.

Awal mula Islam masuk Spanyol pada masa Khalifah al-Walid bin Abdul Malik (705-715), merupakan khalifah Daulah Umayyah yang berpusat di Damaskus. Terdapat tiga pahlawan Islam yang dapat dikatakan telah berjasa dalam proses penaklukan Spanyol. Mereka adalah, Pertama, Tharif bin Malik, sebagai pasukan perintis dan penyelidik beliau merupakan orang pertama yang sukses menyeberangi selat antara maroko dan eropa. Dalam penyelidikan Tharif membawa pasukan sebanyak 500 pasukan dengan 4 buah kapal. ${ }^{3}$ Kedua, Thariq bin Ziyad, sebagai pasukan penakluk dengan 12.000 pasukan Islam berhasil mengalahkan pasukan RajaRoderick dengan membawa 70.000 pasukan. ${ }^{4}$ Ketiga, Musa bin Nusair, dia berangkat dengan pasukan besar menyeberangi selat pada tahun 712 M. Mereka berhasil menaklukan daerah-daerah sampai ke pegunungan Pyrenia di utara dan selatan Perancis. ${ }^{5}$

Kemajuan peradaban dan ilmu pengetahuan yang dimiliki umat Islam mempunyai andil dalam memajukan bangsa Spanyol. Pada masa kekuasaan Dinasti Bani Umayyah di Spanyol mencapai puncak kekuasaannya pembangunan infrastuktur berkembang pesat termasuk yang paling menonjol yaitu menjadikan kota cordova sebagai ibu kota sekaligus menjadikannya pusat pendidikan. Pada masa pemerintahnya kemajuan umat Islam di Spanyol berawal pada masa Abd al-Rahman al-Dakhil, dengan berdirinya Daulah Bani Umayyah di Andalusia yang terpisah dari kekuasaan Bani Abbas di Bagdad pada tahun $756 \mathrm{M}$. Kemajuan yang dicapainya umat isalam di Spanyol sangat ditentukan oleh adanya penguasa-penguasa yang kuat dan beribawa, sehingga mampu mempersatukan kekuatan-kekuatan umat Islam. Diantara Pemimpin Bani Umayyah yang memainkan peranan penting dalam memajukan Andalusia adalah Abdurrahman al-Dakhil, Hisyam I, Hakam I, Abdurrahman alAusat, Muhammad Ibn al Rahman, Munzir Ibn Muhammad, Abdullah Ibn Muhammad dan Abdurrahman al-Nasir. Diantara pemimpin-pemimpin Bani Umayyyah tersebut, Muhammad Ibn al Rahman yang dikenal dengan Muhmmad I merupakan seorang Amir yang mampu memajukan Bani Umayyah pada bidang filsafat dan sains hingga mencapai puncak kejayaannya. Pada masa pemerintahan Muhammad Ibn al Rahman banyak 
melahiran tokoh filsafat muslim yang mewarnai pekembangan filsafat dan sain di Eropa. ${ }^{6}$

Karya tulis ini akan mengkaji lebih dalam terkait dengan kemajuan ilmu pengetahuan dan sains yang dicapain islam di Spanyol pada masa pemerintahan Muhammad Ibn al Rahman. Kemajuan perkembangan ilmu pengetahuan yang dicapai umat muslim di Spanyol membukatikan pada masa kejayaanya islam menjadi Agama dengan peradaban yang sangat berkembang serta berpengaruh bagi kebangkitan peradaban Eropa khususnya pada bidang filsafat dan sains.

\section{Keberagaman Penduduk Andalusia}

Penduduk Andalusia terdiri dari banyak suku, antara lain, Arab, Barbar, Spanyol, dan Yahudi. Bangsa Arab dan Barbar datang ke Spanyol sejak masa penaklukan negeri Spayol oleh pasukan Islam. Keturunan Arab ini terdiri dari dua kelompok besar, yaitu keturunan Arab Utara yang terdiri dari suku Mudhari dan keturunan Arab Selatan yang terdiri dari suku Yamani. Kebanyakan orang Arab Mudhari tinggal di Toledo, Saragossa, Sevilla dan Valensia, sedangkan orang Arab Yamani banyak bermukim di Granada, Cordova, Sevilla, Murcia dan Badajoz. Orang-orang Barbar banyak tinggal di daerah-daerah perbukitan yang kering dan tandus di bagian utara negeri itu, berhadapan langsung dengan basis-basis kekuatan Nasrani sedangkan orang Arab menempati lembah-lembah yang subur serta jauh dari ancaman orang Nasrani. Perbedaan daerah tinggal antara suku Arab dan Barbar diantaranya yang menjadi menyebabnya ketidak puasan orang Barbar terhadap orang Arab yang pada kahirnya menjadi penyulut bagi terjadinya perang antara mereka. ${ }^{7}$

Pada masa ini orang Spanyol terdiri dari tiga kelompok, (1) kelompok yang telah memeluk Islam, (2) kelompok yang tetap pada keyakinannya tetapi meniru adat kebiasaan orang Arab. Baik bertingkah laku maupun bertutur kata, mereka disebut Spanyol musta'ribah, dan (3) kelompok yang tetap berpegang teguh pada agama nenek moyangnya semula dan warisan nenek moyangnya. Tidak sedikit di antara pemeluk agama Nasrani ini yang menjadi pejabat sipil, militer dan bahkan sebagai pemungut pajak serta menikmati kebebasan beragama yang cukup luas. Sedangkan orang Yahudi banyak datang ke Spanyol pada tahun $133 \mathrm{M}$. bersamaan dengan bangsa Romawi menguasai Spanyol. ${ }^{8}$ 


\section{Periodesasi Pemerintahan Daulah Umaiyah di Andalusia}

Sejak Islam masuk Spanyol sampai berakhirnya kerajaan Islam di sana selama lebih dari tujuh abad, dapat dibagi dalam empat periode yaitu; masa ke-Amiran, masa ke-Khalifahan, masa al Muluk, dan masa Reconquista (Penaklukan Kembali) yang dapat diuraikan sebagai berikut;

\section{a) Masa Ke-Amiran}

Periode pertama, (710-755 M), yaitu sejak masuknya Islam ke Spanyol sampai terbentuknya daulah Umayyah di sana. Pada periode pertama ini, Islam di Spanyol mengalami goncangan sehingga terjadi 20 kali pergantian gubernur selama 45 tahun karena tidak ada gubernur yang tangguh yang mampu mempertahankan kekuasaannya untuk jangka waktu yang agak lama. Gangguan banyak terjadi, baik dari dalam atau dari luar. Gangguan dari dalam berupa perselisihan antara elite penguasa terutama akibat perbedaan etnis dan golongan.Di samping itu terdapat perbedaan pandangan antara khalifah Damaskus dari Gubernur di Afrika Utara yang berpusat di Qairawan. Masing-masing mengakui bahwa merekalah yang paling berhak menguasai daerah Spanyol. Oleh karena itu hampir terjadi 20 kali pergantian wali (Gubernur) dalam waktu yang amat singkat. Perbedaan pandangan politik itu menyebabkan sering terjadinya perang saudara. Hal ini pundi sebabkan perbedaan etnis, terutama bangsa Barbar dari Afrika Utara dan Arab. Dalam bangsa Arab terdapat dua golongan yang sating bersaing yaitu suku Quraisy (Arab Utara)dan Arab Yamani (Arab Selatan). Gangguan dari luar datang dari sisa-sisa musuh IslamSpanyol yang bertempat tinggal di daearh-daerah yang tidakpernah tunduk kepada pemerintahan Islam.Ketika gerakan Abbasiyah berhasil menjatuhkan Bani Umayyah tahun 750 M, maka berdirilah khalifah Bani Abbas dengan mengambil Baghdad sebagai pusat pemerintahan.Bersamaan dengan itu, Emirat di Spanyol menyatakantunduk dengan Baghdad. ${ }^{9}$

Konflik politik ini berakhir setelah Abd. al-Rahman al-Dakhili datang ke Spanyol pada tahun $755 \mathrm{M}$. Gangguan dari luar datang dari sisa-sisa musuh Islam di Spanyol yang bertempat tinggal di pegunungan pyrenia bagian utara Spanyol yang tidak pernah tunduk kepada kekuasaan Islam, dan kelak mereka inilah yang mengusir Islam dari Spanyol. Juga datang dari kalangan umat Islam sendiri, berupa perselisihan elit politik. Jadi pada periode ini stabilitas politik negeri Spanyol belum tercapai secara sempurna. Pembangunan baik dalam di bidang peradaban dan budaya 
belum terlaksana sampai Abd. al-Rahman al-Dakhili diangkat menjadi Amir. ${ }^{10}$

Pada periode ke-Amiran terjadi pada (756-912 M.), yaitu sejak pembentukan Pemerintahan Daulah Umayyah di Spanyol di bawah seorang yang bergelar Amir (gubernur), tetapi tidak tunduk kepada pemerintahan Islam pusat khalifah Abbasiyah di Baghdad. Pada saat ini daulah Umayyah di Cordova dipimpin oleh tujuh orang amir, yaitu Abdurrahman I (756-788 M), Hisyam I (788- 796), Hakam I (796-822), Abdurrahman II (822-852), Muhammad I (852-886 M), Munzir (886-888 M), Abdullah (888-912 M). ${ }^{11}$

\section{b) Masa Kekhalifahan}

Pada Periode kedua, terjadi pada kurun waktu (912-1012 M.) sampai munculnya kerajaan kecil yang dikenal Muluk al Thawaif . Pada periode ini Spanyol diperintah oleh penguasa yang bergelar kalifah. Maka pada masa ini terdapat dua kahlifah suni di dunia yaitu khalifah Abbasiyah di Bagdada dab Khalifah Umayyah di Spanyol. Di samping terdapat Khalifah Syiah di Afrika Utara. ${ }^{12}$ Terdapat empat khalifah pada masa ini yaitu, Abdurahman III (912-961 M), Hakam II (961-976 M), Hisyam II (976-1000 M), Muhammad II bin Abi Amir atau Hajib al-Mansur (1000-1010 M). ${ }^{13}$ Kehalifahan di Spanyol dimulai dengan naiknya Abdurrahman III menggantikan ayahnya pada usia 21 tahun sebagai khalifah pertama dengan gelar alNash Lidinillah(penegak agama Allah). Pada 301 H/913 M,Abdurrahman III mengumpulkan pasukan militer yang sangat besar. Kemudian tanpa mendapat perlawanan yang berarti,ia dapat menundukkan kota-kota besar di belahan Utara Spanyol. Kemudian Seville suku Barbar dan umat Kristen yang selama ini menjadi perintang tunduk pada Abdurrahman III. Abdurrahman merupakan penguasa Umayyah terbesardi Spanyol. Seluruh gerakan pengacau dan konflik politik dapat diatasinya sehingga negara dapat diamankan. Keberhasilan ini diikuti dengan penaklukan kota Elvira, Jain, Seville. Iajuga berhasil menggagalkan cita-cita Dinasti Fatimiyah untuk memperluas wilayah kekuasaannya di Spanyol. AbdurrahmanIII tidak hanya mengamankan Spanyol dari kehancuran, namun sekaligus menciptakan kemakmuran dan kemajuan Spanyol. ${ }^{14}$

Di bawah pemerintahan Khalifah Abd Rahman III, Spanyol mengalami kemajuan peradaban yang menggembirakan, terlebih di bidang Arsitektur. Tercatat tidak kurang dari 300 masjid, 100 istana megah, 13.000 gedung, dan 300 tempat pemandian umum berada di Cordova. Kemasyhurannya sebagai penguasa dikenal sampai di negeri Konstantinopel, Jerman, 
Perancis, hingga Itali. Bahkan, penguasa negeri-negeri tersebut mengirim para dutanya ke Istana Khalifah. Armada laut yang dibentuk berhasil menguasai jalur lautan tengah bersama dengan armada Fatimiyyah. Kebesaran Abd Rahman III dapat disejajarkan dengan Raja Akbar dari India, Umar bin Khattab, dan Harun al Rasyid. Jadi, Abdurrahman III bukan hanya sebagai penguasa terbaik Spanyol, melainkan juga salah satu penguasa terbaik dunia. ${ }^{15}$

\section{c) Periode Muluk al-Tawaif}

Pada Periode ketiga terjadi pada kurun waktu, (1010-1492 M.) yaitu di masa kemunduran pemerintahan Islam yang dipimpin oleh Muluk alThawaif (raja-raja golongan) atau Negara-negara kecil yang berpusat di propinsi-propinsi, seperti Seville, Cordova, Toledo dan sebagainya. Mereka itu adalah Sulaiman (1009-1010 M), Hisyam II (1010-1013 M), Sulaiman 1013-1016 M), Abdurrahman IV (1018 M), Abdurrahman V (1023 M), Muhammad III (1023-1025 M) dan Hisyam III (1027-1031 M). ${ }^{16}$ Periode Muluk al-Tawaif Dalam perkembangan selanjutnya, Spanyol terpecah menjadi lebih 30 negara-negara kecil di bawah peme-rintahan raja-raja golongan atau Muluk al-Tawaif yang berpusat disuatu kota seperti Seville, Cordova, Toledo dansebagainya. Yang terbesar di antaranya adalah Abbadiyahdi Seville. Pada masa ini, ummat Islam kembali memasukimasa pertikaian intern. Jika terjadi perang saudara diantarapihak-pihak yang bertikai, mereka meminta bantuan padaraja Kristen. ${ }^{17}$

Melihat keadaan dan kelemahan yang menimpa Islam, untuk pertama kalinya orang-orang Kristen mengambil inisiatif penyerangan. Meskipun kehidupan politik tidak stabil, tetapi kehidupan intelektual terus berkembang pada periode ini. Istana-istana mendorong para sarjana dan sastrawan untuk mendapatkan perlindungandari satu istana ke istana lainnya. Pada perkembangan selanjutnya, Spanyol terpecah menjadi beberapa negara, tetapi terdapat suatu kekuatan yang dominan yaitu Dinasti Murabbithun (1086-1143 M) dan Dinasti Muwahhidun (1145-1235 M). Setelah berakhirnya kekuasaan Murabithun yang berkuasa 25 tahun, Andalusia kembali dikuasai oleh dinasti-dinasti kecil, sampai akhirnya datang orang-orang Mu-wahhidun di bawah khalifahnya Abu Ya'cub Yusuf (1170-1223 M). Kemudian Nasyiriah di Granada merupakan entitas politik Islam terakhir yangmampu bertahan di Andalusia sampai tahun 1492 M. ${ }^{18}$ 


\section{d) Periode Reconquista (Penaklukan Kembali)}

Penaklukan semenanjung Iberia oleh pihak Kristen kemunduran invasi muslim di Spanyol mulai berlangsungsemenjak kekalahan mereka dalam perang Covadonga pada $102 \mathrm{H} / 720 \mathrm{M}$ oleh serangan komando pelayo dari Austria. Kekalahan ini dilanjutkan dengan kekalahan yang me-nentukan nasib mereka dalam perang Tours tahun 114 H/732 M dalam menghadapi Charles Martel.Visigoht yang terdesak oleh invasi bangsa Arab Barbar mencari perlindungan kepada pelayo di Austria, mereka mengangkat sebagai raja mereka dan menjadikan propinsi Austria sebagai wilayah pemerintahannya terlepas daripemerintahan muslim yang menguasai seleuruh wilayah Spanyol. Dari wilayah ini dan dari bagian timur Spanish March, yakni sebuah wilayah perbatasan yang dibentuk olehsuku Franks, mulai merencanakan gerakan pertentanganterhadap penguasa muslim di Spanyol, yang akhirnyapertentangan ini berkembang menjadi gerakan Reconquest(Gerakan penaklukan kembali).Bersamaan dengan penyebaran ini dari Austria,tumbuhlah kubu pertahanan yang berpusat di Burgos. Iamerupakan wilayah pertama yang disebut Castilla, wilayahberbenteng. Tonggak awal gerakan reconquest ini berkaitanIslam Di Andalusia ${ }^{19}$

Perkembangan kerajaan Kristen sekitar abad ke 4 H/11 M bersamaan dengan kemunduran dinasti muslim di Cordova. Kemunduran ini berlangsung sepeninggal Abdurrahman III dan al-Mansur Billah dan pemerintahan Islam dalam keadaan desintegrasi yang mengalami perpecahan menjadi sejumlah kesultanan kecil yang disebut Thawa'if. Persaingan di antara mereka bersamaan dengan ketidak mampuan sejumlah penguasa dalam menciptakan keadaan stabil, merupakan faktor-faktor pendukung kehancurannya. Sampai pada saat itu gerakan recinquest berjalan dalam sejumlah pertumbuhan kecil, dan kemudian,gerakan ini memasuki fase baru dengan gerakan yang sangat menonjol, ia mengalahkan Leon dan ia segera memprakasai kesatuan pertahanan untuk menghadapi pihak muslim yang berkuasa di Spanyol. Penaklukan kota Toledo pada tahun 478 H/1085 M,sebuah kota yang tetap dipertahankan lamaran posisinya yang strategis dan membuka kesempatan bagi Alfonso untuk menjalin hubungan dengan Emir. Hal ini menimbulkan keprihatinan pihak penguasa Thawai'f lainnya akan adanya ancaman. Untuk itu mereka meminta bantuan ke Afrika Utara. Sikap semacam, ini menimbulkan ancaman besar sebab mereka sama halnya mendatangkan kekuatan asingke Spanyol. ${ }^{20}$

Bantuan untuk Sultan-sultan di Spanyol datang dari penguasa alMoravids di Afrika Utara, yakni Yusuf IbnTasyfin berhasil menyatakan 
kekuatan muslim, sehingga mereka berhasil memasuki militer Kristen pada pertempuran di al-Zallaqah (Sagrajas yang berdekatandengan Badajoz) pada tahun 476/1086. Tidak lama kemudian terbentuklah kelompok ksatria di Calatrava,Santiago dan al-Cantara, yang akhirnya semakin memperkuat posisi pasukan Salib. Di Portugal Alfonso I secara mutlak menaklukkan wilayahnya sendiri pada tahun 543/1148 dengan bantuan pasukan Salib Inggris, Perancis dan Jerman.Selama masa dominasi Perancis, pihak gereja mengambilsejumlah peribadatan ala bangsa Romawi ke dalam istanaVisighotic, yang menandai bahwasanya negeri ini sekarangbenarbenar menjadi bagian dari Eropa dan tidak lagi sebuah negeri yang berdiri sendiri.Untuk melawan kekuatan al-Mohads, sebuah dinastiyang mengalahkan al-Moravids, kerajaan-kerajaan kecil Spanyol mengadakan persekutuan dan membentuk bantuangabungan dari Castille, Aragon, Navarre dan jugs bergabungkembali dengan militer Portugis. Mereka berhasil me-ngalahkan al-Mohads (alMurabithun) pada pertempuran LasNavas de Tolosa pada 609/1212, sebuah pertempuran yangsangat penting dalam gerakan reconquest, yang pada akhirnyamenyebabkan kehancuran Cordova pada tahun 634/1236dan kehancuran Seville pada tahun 646/1248. ${ }^{21}$

Satu-satunya Islam Di Andalusia pernerintahan muslim adalah Granada yang pada saat itubernaung di bawah kedudukan Cadiz sebagai negara pembayar upeti. Benteng pertahanan muslim setelah ditundukkan pada pertempuran di Las Navas, sekarang pertahanan mereka tinggal berada di sekitar lokasi Biara diLas Huelgas Realis di Bugles.Dengan terbentuknya kesatuan Spanyol di bawah raja-raja Katolik, yakni Ferdenand dan Isabella, tibalah saatnya untukmenyatukan mereka dalam barisan, kemudian terjadilah sebuahkejutan besar, ketika serangan pasukan Kristen dalam jumlahyang sangat besar terhadap Granada berhasil dihindarkan. Padaperkemahan San Fe, Isabella bersumpah bahwasanya ia tidakakan melepaskan pakaiannya sampai Granada ditaklukkan. Sebuah sumpah yang menyebabkan kesulitan baginya. Sebabternyata Granada tetap bertahan selama dua tahun lebih. Padatahun 1492 Granada yang merupakan kerajaan muslim terakhirdi Spanyol menyerah. Pada pertengahan abad ke 16 muslimSpanyol mengerahkan aksi pemberontakan terakhir yangberusaha merebut kembali kekuasaan atas Granada, tetapi tidak berhasil. Pada tahun 1619 warga Moors (muslim Spanyolketurunan Arab) secara sewenang-wenang dipaksa me-ninggalkan Islam dan memeluk agama Islam, atau mereka harus meninggalkan Spanyol. Sejumlah mereka bertahan menjalankanajaran Islam secara sembunyi-sembunyi bahkan bisa 
jadiberlangsung sampai sekarang. Pada masa sekarang ini sejumlahgroup etnis seperti Maragatos-Astorga de Leon merupakanketurunan kelompok Mooris. ${ }^{22}$ Daftar Nama Para Khalifah Daulah Umaiyah di Andalusia

a) Abdurrahman I (756-788 M)

b) Hisyam I (788-796)

c) Hakam I (796-822)

d) Abdurrahman II (822-852)

e) Muhammad I (852-886 M)

f) Munzir (886-888 M)

g) Abdullah (888-912 M)

h) Abdurahman III (912-961 M)

i) Hakam II (961-976 M)

j) Hisyam II (976 M)

k) Muhammad II bin Abi Amir atau Hajib al-Mansur (976- 1009 M)

1) Sulaiman (1009-1010 M)

m) Hisyam II (1010-1013 M)

n) Sulaiman 1013-1016 M)

o) Abdurrahman IV (1018 M)

p) Abdurrahman V (1023 M)

q) Muhammad III (1023-1025 M)

r) Hisyam III (1027-1031 M) ${ }^{23}$

\section{Perkembangan Ilmu Pengetahuan Dan Sains Bani Umayyah di} Andalusia

Pada masa pemerintahan Abdurrahman Ad-Dakhil umat Islam di Andalusia mulai memperoleh kemajuan-kemajuan baik dalam bidang politik maupun dalam bidang peradaban. Abdurrahman ad-Dakhil merupakan seorang amir yang sangat memperhatikan fasilitas peribadatan umat Islam. Pembangunan masjid cordova menjadi masjid termegah pada masanya menjadi bukti perhatinnya. Untuk mencerdaskan rakyatnya Abdurrahman al-Dakhil juga memperhatikan sarana-sarana pendidikan dengan mendirikan sekolah-sekolah di kota-kota besar yang ada di Andalusia dan menjadikan Cordova sebagai ibu kota serta menjadi pusat pemerinthan di Spanyol. Abdurrahman al-Dakhil yang memerintah selama kurnag lebih 30 tahun yaitu pada tahun 755-788 M. ${ }^{24}$ Setelah kepemimpinan Abdurrahman I (al-Dakhil), penguasa silih berganti, namun penguasa-penguasa yang mampu mengembangkan Bani Umayyah pada masa pemerintahan Hisyam I beliau memerintah pada tahun 788-796 M, memerintah menggantikan 
ayahnya Abdurrahman I. Pada masa pemerintahnya Hisyam I dapat memperluas kekuasaannya, karena Saragossa dan Barcelona mengakui pula kekuasaan Daulah Umayyah di Spanyol. Dalam bidang ilmu, Hasyim I menghormati imam Malik, salah satu mazhab dari empat mazhab fiqih di kalangan Sunni. Dia mendorong para pencari ilmu, agar melakukan perjalanan ke Madinah guna mempelajari ajaran-ajaran mazhab Maliki. Kitab al-Muwatho' yang ditulis Imam Malik disalin dan disebarluaskan ke seluruh wilayah kekuasaannya. ${ }^{25}$ Setelah meninggal Hisam I digantikan oleh anaknya Al-Hakam bin Hisyam yang memerintah pada tahun 796821 M. Pada masa pemerintahnya Hakam dikenal sebagai pemimpin yang suka pada kemewahan sehingga pada masa pemerintahanya kurangnya kontribusi dalam mengembangkan islam. ${ }^{26}$ Setelah kepemimpinan Hakam dilanjutkan oleh Abdurrahman II (Ausat) Bin Hakam pada tahun 821$852 \mathrm{M}$, dikenal sebagai pembaharu dalam bidang kemiliteran. Selain perkembangan dalam bidang kemiliteran Abdurrahman II beliau juga mengembangkan kesenian dan kesusastraan, beliau sangat mencintai kesenian dan kesusasteraan dan mencintai masyarakat yang berbakat dan berilmu. Sehingga para seniman dan cendekiawan berduyunduyun mengunjungi istananya, belum pernah istana para sultan, seperti di bawah kekuasan Abdurahman II. Beliau banyak memberikan hadiah kepada para seniman, penyair, dan musisi, Abdurrahman II menjadikan Cordova sebagai Baghdad kedua. Abdurrahman II merupan pemimpin yang aktif dalam pembangunan pada masa pemerintahnya beliau memperindah kota dengan gedung-gedung besar, masjid masjid, taman-taman, sehingga dia dapat menjadikan Cordova sebagai kota kebudayaan yang indah, budi bahasa yang halus, sopan santun Arab yang anggun, yang kemudian ditiru oleh orang-orang Eropa. Setelah menjalankan pemerintahannya selama 30 tahun, beliau meninggal dunia pada tahun 852 M. ${ }^{27}$ Setelah pemerintahan Abdurrahman Bin Hakam dilanjutka oleh anaknya Muhammad I beliau memerintah pada tahun 852-886 M seperti ayahnya, beliau pencinta seni keindahan, memperindah Ibu Kota dengan gedung-gedung indah, bangunan-bangunan besar, serta monument-monumen, Muhammad I meninggal dunia dalam usia 65 tahun. Peranan besar beliau pada masa pemerintahannya merupakan pemimpin yang memprakarsai lahirnya tokoh filsafat islam. kepribadian beliau yang pencinta ilmu, penyokong belajar, penyair dan penulis berdampak pada perkembangan islam dalam bidang sains dan filsafat. Salah satu usaha besar beliau dalam memajukan perkembangan filsafat dan sains dengan cara mengundang para ahli dari dunia Islam untuk datang ke Andalusia untuk mengkaji ilmu pengetahuan. 
Pada masa pemerintahannya pemikiran Filsafat mulai dikembangkan umat Islam. $^{28}$

Perkembangan yang dicapai Bani Umayyah pada masa pemerintahan Muhmmad I di Spanyol bukan berarti jauh dari ancaman dan kerusuhan. Pada pertengahan abad ke-9 stabilitas negara terganggu dengan munculnya Kristen fanatik yang mencari kesyahidan. Namun gerakan ini tidak mendapat simpati dari gereja Kristen lainnya. Karena itu pemerintah Islam mengembangkan kebebasan beragama. Penduduk Kristen diperbolehkan memiliki pengadilan sendiri berdasarkan hukum Kristen. Dalam bidang politik juga terjadi kemelut yang berkepanjangan. Pemberontak terjadi di Toledo pada tahun $852 \mathrm{M}$ membentuk negara kota yang berlangsung selama 80 tahun. Demikian pula halnya bagi orang yang tak puas dengan sistem pemerintahan yang ada membangkitkan revolusi. Di lain pihak perselisihan juga terjadi antara orang Bar-bar dan orang-orang Arab.

\section{Muhammad Ibn Abd Al-Rahman dan Peranannya Dalam mengembangan Filsafat Dan Sains Di Andalusia}

a) Biografi Muhammad Ibn Abd Al-Rahman

Muhammad I merupakan putra Abdurrahman Bin Hakam seorang pemimpin ke-4 Dinasti Umayah di Spanyol. Muhammad I memiliki nama lengkap Muhammad Ibn Abd Al-Rahman beliau memerintah menggantikan ayahnya yang meninggal dunia. Beliau memerintah kurang lebih 30 tahun yaitu pada tahun 852-886 M. Pada awal mula Muhmmad I mejabat menjadi kepala pememerintahan terjadi serangkaian kerusuhan dalam negeri. Kegoncangan pemerintahan bemula dari pemberontakan Rakyat Toledo, dibantu kepala suku Leon memberontak pada tahun $854 \mathrm{M}$. Mengetahui pemberontakan rakyat Toledo Muhammad I segera berangkat dengan membawa pasukan besar dan memaksa para pemberontak tunduk, pada pertempuran itu terdapat sekitar 8.000 orang Kristen dibunuh karena tidak tunduk pada pemerinthan. Bangsa Norman muncul melakukan kerusuhan kerusuhan, orang-orang Franka menyerbu Spanyol, diikuti orangorang Galisia dan Navarre. Setelah berhasil mengatasi kerusuhankerusuhan, Muhammad I mengorganisir pemerintahan Andalusia secara teratur dan membuat sitem peraturan ketata pemerintahan dalam bentuk perundang-undangan bagi pengelolaan Negara, beliau juga melakukan kebijakan-kebijakan pemerinthan yang mengarah pada mensejahterakan kehidupan rakyat dengan dengan memberikan 
bantun pada rakyat yang kurang mampu. Sebagai seorang amir yang mencinta ilmu, beliau penyokong fasilitas bagi pendidikan, serta para penyair dan penulis turut mendapatkan perhatiannya. Seperti ayahnya, salah satu kpribadian beliau yang sangat pencinta seni keindahan, pada masa pemerinthannya beliau membangun kota dengan memperindah Ibu Kota dengan gedung-gedung indah, bangunan-bangunan besar, serta monument-monumen. Pada usia 65 tahun bertepatan pada tahun $886 \mathrm{M}$ beliau meninggal dunia sekaligus menjadi akhir Masa jabatan pemerinthanya. $^{29}$

b) Perkembangan Filsafat dan Sains

Kemajuan filsafat dan Sains Islam di Spanyol telah mencatat satu lembaran budaya yang sangat briyan dalam bentangan sejarah Islam. Minat terhadap filsafat dan ilmu pengetahuan Yunani mulai dikembangkan pada abad ke $9 \mathrm{M}$ selama pemerintahan BaniUmayyah ke lima, yaitu Muhammad ibn Abd al-Rahman(832-886 M) atas inisiatif al-Hakam (961-976 M), karya-karya ilmiah dam filosofis diimport dari Timur dalam jumlah besarsehingga Cordova dengan perpustakaan dan Universitasnya mampu menyaingi Baghdad sebagai pusat utama ilmu pengetahuan di dunia Islam.Kemajuan di bidang Horn filsafat ditandai dengan lahirnya tokoh-tokoh terkenal Ibn Bajjah, Ibn Tufail dan Ibn Rusyd. Ibnu Bajjah dilahirkan di Saragosa tahun 1136 M,karya yang terkenal adalah The Rule of The Solitary, dia juga terkenal di bidang ahli Matematika, Astronomi dan Musik. Ibnu Tufait di Barat dengan nama Abu Bacer, ia lahir di Granada, terkenal di bidang kedokteran di samping bidang filsafat. Karyanya Ibnu Tufait yang terkenal Hay ibn Yaqdhan. Ibnu Rusyd adalah filsafat besar yang berpengaruh di Barat, ia dilahirkan di Cordova tahun 1126. Di Eropa dikenaldengan nama Averoes. la tekenal juga di bidang Astronomi dan Kedokteran. Averoes juga berjasa dalam membuat ringkasan dan tafsiran-tafsiran filosof Yunani. Karyanya yangterkenal adalah Tahafut al Tahafut dan Fashl al-Maqal. Sejalan dengan perkembangan filsafat, Sains me-rupakan bidang yang sama-sama berkembang dengan pesat di Spanyol Islam. Ilmu-ilmu kedokteran, Matematika, Astronomi dan Kimia maju pesat. Abbas ibn Famas termasuk dalam ilmu Kimia dan Astronomi, ialah orang pertama yang menemukan kaca dan batu. Ibrahim ibn Yahya al Naqqash terkenal dalam ilmu Astronomi. Ia dapat menemukan waktu terjadinya gerhana matahari dan menemukan berapa lama. Ia berhasil membuat teropong modem yang dapat menemukan jarak antara tata surya dan bintang-bintang. Abroad ibn Ibas dari Cordova adalah ahli 
dalam bidang obat-obatan. Umm al-Hasan binti Abi Ja'far dan saudara perempuan al Hafidz adalah dua o-rang ahli kedokteran dari kalangan wanita . Di antara ahli Astronomi lainnya yang mashur saat itu adalah al Mariti dari Cordova, al Zuqoli dari Toledodan Ibn Aflad dari Seville. Al Majariti dikenal sebagai salahseorang pakar yang berhasil mengedit dan mengkoreksi perbintangan al Khawarizmi.Dalam bidang sejarah dan geografi, wilayah Islam bagian barat melahirkan banyak pemikir terkenal. Ibn Jubairdari Valencia (1145-1228 M), menulis tentang negeri-negeri muslim Mediterania dan Sicilia dan Ibn Batuthah dari Tangier.Islam Di Andalusia (1304, 1377 M) mencapai Samudera Pasai dan Cina. IbnualKhotib (1317-1374 M) menyusun riwayat Granada,sedangkan Ibnu Khaldun dari Tunis adalah perumus filsafatsejarah. Semua sejarawan di atas bertempat tingal di Spanyolyang kemudian pindah ke Afrika.

c) Pengaruh Terhada Kebangkitan Peradaban Eropa

Kemajuan Eropa saat ini tidak dapat dimungkiri banyak berhutang budi kepada khazanah ilmu pengetahuan Islam yang berkembang di periode klasik, termasuk yang di Baghdad dan terutama yang di Spanyol. Banyak saluranperadaban Islam mempengaruhi kebangkitan Eropa, yang terpenting di antaranya adalah Spanyol Islam kemudian Perang Salib. Spanyol Islam merupakan tempat yang paling utama bagi Eropa menyerap dan menyadap peradaban Islam. Karena Orang Eropa menyaksikan secara nyata bahwa Spanyol yang berada di bawah kekuasaan Islam jauh meninggalkan negara-negara Eropa lainnya, termasuk tetangganya, seperti Perancis, Jerman, Portugal dan lainlainnya, terutama dalam bidang pemikiran dan sains, maupun bangunan fisik. Pengaruh peradaban Islam yang terpenting, dari Spanyol Islam adalah; pertama, pemikiran Ibn Rusyd (1120- 1198 M.). Pemikirannya dapat melepaskan orang Eropa dari belenggu taklid yang sudah berurat berakar dan menganjurkan kebebasan berpikir. Karena Ibn Rusyd mengulas pemikiran Aristoteles dengan cara yang memikat, sehingga mengundang minat orang banyak yang berpikiran bebas. Ia mengedepankan pengertian sunnatullah menurut Islam terhadap pantheisme dan anthropomorphisme Kristen. Begitu besarnya pengaruh pemikiran Ibn Rusyd di Eropa sehingga timbul gerakan Averroeisme (Ibn Rusyd-isme) yang menuntut kebebesan berpikir. Tetapi pihak gereja menolak pemikiran rasional yang dibawa gerakan Averroeisme ini. Berawal dari gerakan Averroeisme inilah kemudian di Eropa melahirkan gerakan reformasi pada abad ke-16 M. Dan gerakan rasionalisme pada abad ke-17 M. melalui buku-buku Ibn Rusyd yang dicetak di Venesia, 
tahun $1481,1482,1483,1489$ dan 1500 M., edisi lengkapnya pada tahun 1553 dan 1557 M. Juga di terbitkan pada abad ke-16 M. di Napoli, Bologna, Lyonms, dan Strasbourg dan di awal abad ke-17 di Jenewa. Kedua, saluran lainnya, adalah melalui mahasiswamahasiswa Kristen Eropa yang belajar di Universitasuniversitas Islam di Spanyol, seperti Universitas Cordova, Seville, Malaga, Granada dan Salamanca. Selama belajar di Spanyol mereka aktif menerjamahkan dan mempelajari bukubuku karya ilmuwan-ilmuwan muslim. Setelah pulang ke negerinya, mereka mendirikan sekolah-sekolah dan Universitas-universitas yang sama di Eropa. Seperti Universitas Paris yang didirikan pada tahun 1231 M merupakan Universitas pertama di Eropa, dia didirikan setelah tiga puluh tahun Ibn Rusyd wafat. Dalam perkembangannya, di akhir Periode Pertengahan telah berdiri 18 Universitas. Di dalam Universitas-universitas itu, mereka ajarkan ilmu yang mereka peroleh dari Universitas-universitas Islam, seperti ilmu pasti, ilmu kedokteran dan filsafat.Pemikiran filsafat yang paling ba nyak dipelajari adalah pemikiran al-Farabi, Ibn Sina dan Ibn Rusyd. Maka pengaruh ilmu pengetahuan Islam atas Eropa yang sudah berlangsung sejak abad ke-12 M. hingga abad ke-14 M. itu menimbulkan kembali gerakan kebangkitan renaissance pusaka Yunani di Eropa pada abad ke-14 M. Kebangkitan kembali pemikiran Yunani di Eropa kali ini adalah melalui terjamahan-terjamahan Arab, kemudian diterjamahkan kembali ke dalam bahasa Latin. Dengan demikian, pengaruh peradaban Islam Spanyol telah dapat melahirkan tiga gerakan penting bagi kebangkitan Eropa. Pertama, gerakan kebangkitan kembali kebudayaan Yunani kuno atau klasik (renaissance) pada abad ke-14 M. bermula di Italia, Kedua, gerakan reformasi pada abad ke-16 M. Ketiga, gerakan rasionalisme pada abad ke-17 M. Selanjutnya Eropa bangkit dari ketertidurannya selama ini. Ketiga, Perang Salib, meskipun pihak Kristen Eropa mengalami kekalahan dalam Perang Salib akan tetapi mereka mendapatkan hikmah yang tidak ternilai harganya, sebab mereka dapat menyaksikan dan berkenalan langsung dengan peradaban Islam yang sudah maju menyebabkan lahirnya renaisans di Eropa. Adapun peradaban yang mereka bawa ke Barat lewat Perang Salib terdiri dari kemajuan peradaban Islam di bidang militer, seni, perindustrian, pertanian, perdagangan, astronomi, kesehatan dan sikap kepribadian umat Islam yang luhur yang tidak mendapat perhatian di Barat sebelumnya. 


\section{Simpulan}

Peradaban islam di Spanyol menjadi bukti bahwa pada masa kejayaannya islam mampu memperluas wilayah sampai Eropa. Prestasi besar yang pernah diraih Islam menjadi bukti bahwa Agama islam pernah menjadi Agama yang menguasai hampir seluruh dunia. Suatu yang penting yang perlu digaris bawahi bahwa Ekpasni yang dilakuakn Islam dalam perluasan wilayah tidak pernah meninggalkan kerusakan pada bangsa tersebut bahkan cenderung memajukan peradaban bangsa jajahan. Ekpansi militer dengan jalan peperangan yang dikaukan Islam tidaklah hanya sebatas memeperluas wilayah demi kepentingan politik namun terdapat nilai peradaban. Seperti ekpansi yang dilakukan islam di Spanyol, dalam perjalanan perluasan wilayah tersebut Islam tidak menjarah dengan mengeruk hasil alam dan tidak menindas penduduk pribumi Spanyol. Sebagai agama yang Rahmatan lil Alamin islam benar-benar memegang konsep tersebut. Kebijakan pemerintahan Islam di Spanyol membebaskan dalam beragama. Islam tidak memaksaan penduduk pribumi Spanyol yang beraneka latar belakang agama sperti yahudi, nasrani dan agama nenek moyang yang dikenal dengan agama romawi. Islam hanya menekankan bahwa setiap warga Spayol boleh memeluk Agama selain Islam akan tetapi dengan catatan patuh dan taat terhadap pemerintah Islam. Salah satu kebiajakan pemerintahan Islam yang harus dilakukan oleh bangsa Spayol yaitu memabayar pajak, yang nantinya pembayaran upeti atau pajak ini digunakan untuk biyaya operasioal pemerintahan. Kebijakan pembayaran pajak yang dilakukan pemerintah menjadi salah satu faktor kuat dan majunya Islam dalam mengembangkan peradaban termasuk di Spanyol. Islam di sepanyol khusunya pada pememnritanhan Muhammad I menjadi titik terang lahirnya para tokoh filusuf dan sains muslim. Lahirnya para tokoh Filsafat dan Sains mulim pada pemerintahan Muhammad I sangat dipengaruhi oleh sistem pemerimtahan yang mendukung kemajuan ilmu pengetahuna. Muhammad I merupakan seorang Amir yang dikenal sangat mencintai seni dan ilmu pengetahun. Kencintaanya pada senin dan ilmu pengetahun berdampak pada sistem pemerintahannya yang sangat mendukung dalam pencapaianan keamajuan ilmu pengetahuan. Hal tersebut nampak pada usaha-usaha yang dilakukan Muhammad I seperti usaha besarnya dalam memajukan khazanah ilmu penegetahuan dengan mengundang para ahli dari dunia Islam untuk datang ke Andalusia untuk mengkaji ilmu pengetahuna. Lahirnya tokoh filsafat dan dan sains islam di Spanyol ini yang pada khirnya turut memberikan kontribusi yang sangat 
besar terhadap perkembangan peradaban Spanyol dan kebangkitan peradaban bangsa Eropa khususya pada bidang flsafat dan sains yang masih terasa sampai era sekarang.

\section{Endnotes}

1 Rianawati, Sejarah \& Peradaban Islam, ( Pontianak: STAIN Pontianak Press, 2010), Hlm. 141.

2 H. Syamruddin Nasution, Sejarah Peradaban Islam, ( Riau: Yayasan Pusaka Riau, 2013), Hlm. 139.

3 Philip K H, History of Arabs. Terjemah Cecep Luman Yasin, (Jakarta: Serambi Ilmu Semesta, 205), hlm. 628.

4 A Syabili, Sejarah kebudayaan islam, ( Jakarta: Al-Husna Zikra), hlm. 159.

5 H. Syamruddin Nasution, Sejarah Peradaban Islam..., Hlm. 143.

6 Anonim, Ensklopedi Islam, Jilid 5 (Jakarta: PT Ichtiar Van Hoeve, 2001), hlm. 133.

7 Siti Maryam, Sejarah Peradaban Islam, (Yogyakarta: Lesfi, 2009). Hlm. 83.

$8 \quad$ H. Syamruddin Nasution, Sejarah Peradaban Islam..., Hlm. 148.

9 Rianawati, Sejarah \& Peradaban Islam..., Hlm. 145.

10 Badri Yatim, Sejarah Peradaban Islam, (Jakarta: Raja Grafindo Persada, 1994), hlm. 94.

11 K. Ali, Sejarah Islam, Terjemah M Nasir Budiman, (Jakarta: Raja Grafindo Persada, 1996), hlm. 302.

12 K. Ali, Sejarah Islam, Terjemah M Nasir Budiman..., hlm. 308.

13 H. Syamruddin Nasution, Sejarah Peradaban Islam..., Hlm. 149.

14 Rianawati, Sejarah \& Peradaban Islam..., Hlm. 147.

15 K. Ali, Sejarah Islam, Terjemah M Nasir Budiman..., hlm. 309.

16 H. Syamruddin Nasution, Sejarah Peradaban Islam..., Hlm. 150.

17 Rianawati, Sejarah \& Peradaban Islam..., Hlm. 148.

18 Rianawati, Sejarah \& Peradaban Islam..., Hlm. 149.

19 Rianawati, Sejarah \& Peradaban Islam..., Hlm. 150.

20 Rianawati, Sejarah \& Peradaban Islam..., Hlm. 150.

21 Rianawati, Sejarah \& Peradaban Islam..., Hlm. 151.

22 Rianawati, Sejarah \& Peradaban Islam..., Hlm. 152.

23 H. Syamruddin Nasution, Sejarah Peradaban Islam..., Hlm. 178.

24 Syed Mahmudunnasir, Islam Konsepsi dan Sejarahnya, (Bandung: Rosda Bandung, 1988), hlm. 285.

25 Syed Mahmudunnasir, Islam Konsepsi dan Sejarahnya..., hlm. 289.

26 H. Syamruddin Nasution, Sejarah Peradaban Islam..., Hlm. 154.

27 Syed Mahmudunnasir, Islam Konsepsi dan Sejarahnya..., hlm. 294.

28 H. Syamruddin Nasution, Sejarah Peradaban Islam..., Hlm. 156.

29 H. Syamruddin Nasution, Sejarah Peradaban Islam..., Hlm. 157.

\section{DAFTAR PUSTAKA}

Abidin, Zainal. 1975. Riwayat Hidup Ibn Rusyd. Jakarta: Bulan Bintang. Hasymi. 1979. Sejarah Kebudayaan Islam. Jakarta: Bulan Bintang 
Hitti, Philip K. 1970. Dunia Arab, terj. Ushuluddin Hutagalung dan O.D.P.Sihombing. Bandung: Sumur Bandung.

K. Bertens. 1986. Ringkasan Sejarah Filsafat. Yogyakarta: Kanisius.

Maryam, Biti dkk. 2009. Sejarah Peradaban Islam Dari Masa Klasik Hingga Modern c. 3. Yogyakarta: LESFI.

Nasution, H. Syamruddin. 2013. Sejarah Peradaban Islam. Riau: Yayasan Pusaka Riau.

Nasution, Harun. 1985. Islam Ditinjau Dari Berbagai Aspeknya, Jilid 1, c. 5. Jakarta:UI Press

Rianawati. 2010. Sejarah \& Peradaban Islam. Pontianak: STAIN Pontianak Press.

Tim Penulis. 2001. Ensiklopedi Islam, Jilid 2, c. 9. Jakarta: PT Ichtiar Baru Van Hoeve.

Watt, W. Montgomery. 1990. Kejayaan Islam: Kajian Kritis dari Tokoh Orientalis. Yogyakarta: Tiara Wacana. 